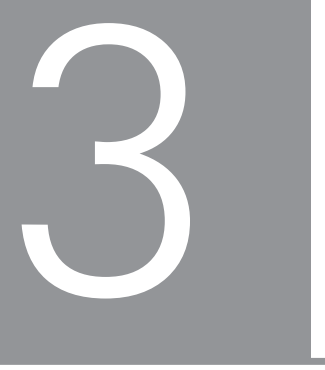

\title{
THE UNIVERSITY AS KEY CONCEPT IN HIGHER EDUCATION STUDIES
}

\author{
A JOURNEY WITH RESEARCH INTO A \\ CONCEPTUAL ANALYSIS OF A UNIVERSITY
}

\section{Laetus OK Lategan}

An occasional look at present ideas in the light of their intellectual origins serves to strengthen our resolution to press on with what we are doing today.

Guy Neave (2001:29)

\section{ABSTRACT}

This chapter considers the questions: "What is a university? Exactly what does a university have to do with higher education studies?" The discussion on what a university is provides a framework that can be used in higher education policy studies in particular and higher education studies in general. The chapter begins from a philosophical perspective and builds on the concepts of continuity and discontinuity. Based on these concepts, it is argued that new knowledge development (research) and knowledge transmission (teaching) are central to the university and have been, throughout the history of universities. What has changed is the way in which these tasks have been performed. Needless to say, the author is well aware that this is but one way of dealing with the question at hand. The author points out that although he has remained true to his own paradigm, this did not prevent him from changing his views on the topic. The chapter highlights that the university is a social organisation consisting of people (ranging from lecturing and managerial staff to students). What is often forgotten is that both people and their activities should be managed. Since the university does not exist in isolation, universities are challenged by partnerships, social engagement and developmental issues. The chapter also highlights some images of the university caused by certain dominant factors impacting on the university, and concludes with some pointers and lessons based on the author's research into the concept 'university'. 


\section{PLANNING THE JOURNEY}

My interest in the question "What is a university?" started some 20 years ago when I wrote a master's dissertation in philosophy on the "nature of the university" (Lategan 1989). Since then I have subscribed to the belief (no religious belief!) that without an understanding of what a university is, it is almost impossible for the university (as an organisation) to operate effectively in society. In addition, I am also of the opinion that this question and the ensuing answers form the basis of all higher education studies. If one says that the university is about social development, then one needs to ask how the university should address this issue. If one argues that the university exists simply to educate students for future careers, then the question would be how best a university can achieve this. Regardless of how one views the university, it should lead one to unpack those activities with which a university concerns itself.

A fundamental understanding of the complexities associated with a university as social organisation and how the university should function within society is central to all higher education studies. This orientation was confirmed over a period of 20 years, and four other observations have strengthened this belief.

Firstly, when I attended my first conference on higher education I realised that this question will always be a fundamental question in higher education studies. It was during the Ninth Biannual Conference of the South African Association for Research and Development in Higher Education (SAARDHE) in 1994 that no fewer than seven of the papers were devoted to some or other attempt to understand the concept 'university'.

Secondly, at the closure of a conference, What kind of University? organised by the Open University in London in 1996, the then Vice-Chancellor Sir John Daniels remarked that perhaps the theme of the conference should rather have been What is a university? His remark (according to my analysis) signalled that for one to understand what kind of university is needed for society one needs to understand what the purpose of a university is.

Thirdly, the UNESCO-awarded higher education researcher, Prof. Ulrich Teichler, observed in his book, Higher Education Systems (2007), that the conceptual analysis of a university is no stranger to higher education policy studies. The university needs to know itself, and to know what factors are impacting on it.

Fourthly, Van Vught (1997) refers to the university as a "micro cosmos" with its own laws and history. He advocates contemporary relevance, but argues for high quality, 
the stimulation of intellectual education and scholarship. Van Vught also reminded me that, since the university and its knowledge are so important, they have to be managed. Some management approaches can be regarded as characteristic of universities. He refers to three characteristics. First, there is the professional character of a university as organisation. Because the university is an organisation, a professional approach to university management cannot be compromised. Second, it should be remembered that the university consists of various disciplines. To this extent the fragmentation of the university should be managed. In the third place, the diversity of decision making in universities should be managed. The challenge is to unify this diversity, to unite the fragmentation and to awaken a new professionalism. He rightly says that a university is more than loose-standing disciplines and activities. Scientific disciplines and activities should jointly contribute towards solving societal challenges.

Many more (and similar) encounters can be sampled. Suffice it to say that the dynamic challenges facing a university as organisation, coupled with the ever-increasing demand for the university to be responsive to societal needs, call for a continuous revisiting of the role of a university. This call is furthermore informed by the postmodern philosophical orientation that neither a fixed structural understanding of what a university is, nor a 'one-size-fits-all' approach exists. On the basis of my rationalistic paradigm of conceptual analysis of a university, I cannot agree with the first statement of the post-modern philosophy (no fixed structure). My own research and exposure (as an employee of a university) have brought me to a fundamental understanding of a university namely that, taking on the metaphor of one-size-fits-all, there is a common size for a university (let's call it its core functions), but that this common size is fitted depending on the feet wearing them (each university takes care of its core functions in a different way). From an intellectual perspective this understanding was influenced by - to name but one uncontested name - Plato's view of continuity and discontinuity in his youth dialogue 'Kratylos'. If the university changes (for example, by adding new university types), is there still a structural identity to be found in the university as a social structure? Is there anything constant in the nature of the university which continues, regardless of any (structural) changes that may occur? Which fundamental structural principle can always be recovered, from the origin of universities, or is each new university and each new period of time purely the product of the organisational creations of humans? Plato realised that all changes can only occur on the basis of constants. No change is possible if there is no foundation for change. With reference to this perspective of Plato, it may be expected that even when the university changes by taking on new forms, the teaching, research and service still have to be continued. 
Although the university community, for example, may change by introducing new university forms (such as the comprehensive university or university of technology in South Africa), this new adjustment can never be removed from that which is typical of the university. [Kerr (1995) provides an excellent account of how a university can change to fit its context without bidding farewell to its core activities. A good example is American universities shifting their focus towards military science after the World Wars. Bok (2003) also describes what can happen to a university if it lets go of what its real purpose is. In his book on commercialisation in higher education he portrays a negative image of a university if it must become a business at all costs.] From an employee perspective this was observed/experienced through encounters such as the (political) transformation of a university, debates on what the core functions of a university really are, the change from a technikon (regarded as a non-university system) to a university (of technology), policy planning and implementation, and so on. This observation, namely that the university can change but its functions remain the same, will be further explored through my journey with research into understanding what a university is.

The broad theme of this contribution is to reflect on the question "What is a university?" Answers to this question will provide some perspectives on what a university is and how it can (best) execute its core functions in a post-industrial corporate society. In answering this question I will reflect, on my own research on this topic (Lategan 1989, 1996, 1998, 2000, 2005), amongst others. The reason for this approach is twofold. Firstly, research involves self-assessment. (Too many researchers never look at their own research.) Secondly, in doing higher education research there is also a need for methodological understanding, review and change. The approach taken to the question in this chapter should also tell something about methodological approaches.

\section{BUYING THE TICKET: A CONCEPTUAL UNDERSTANDING OF WHAT A UNIVERSITY IS}

In answering the question of what a university is, a number of approaches are needed to unpack the conceptual meaning of a university. It may be stated that neither the history of universities, nor the tasks assigned to universities, nor policy directives are sufficient to provide a comprehensive definition of a university (see Lategan 2005). This statement does not mean that policies and history are not important. It simply implies that conceptual knowledge is also needed to understand what a university is. To illustrate this point: 
The history of universities can briefly be divided into four stages (see Lategan 1989, 1998, 2005 for a detailed analysis). During the $12^{\text {th }}$ to the $14^{\text {th }}$ centuries, the medieval universities at Bologna, Parma, Paris and Oxford specialised in the training of professional clergy, lawyers and clerical and lay administrators, and could be regarded as vocational schools. It is not strange that the curriculum consisted of the trivium (grammar, logic and rhetoric) and quadrivium (arithmetic, geometry, astronomy, music and science) at undergraduate level, and theology, law and medicine at the postgraduate level. The former is in line with those subjects offered at the Academy of Plato, the Lukeion of Aristotle and education in general in the ancient Greek World. The $15^{\text {th }}$ to the $19^{\text {th }}$ centuries were characterised by education for the elite. Although the curriculum remained the same as that of the original vocational university, the purpose was not for training, but for education. Following this period, during the $19^{\text {th }}$ century up to the 1950s, knowledge was fragmented in the Cartesian reductionist fashion in which one could isolate a very small domain of possible knowledge and focus one's entire energy on it. The intellectual world became isolated from the world out there. Everything was done for the sake of knowledge. The notion of pure knowledge could of course not accommodate mundane technological enterprises with the result that engineering, for example, was at first avoided and only included in the late $19^{\text {th }}$ century. The 1960s introduced a new era in the existence of universities. University life was characterised by economic growth that led to esoteric studies of an unimaginable number of subjects, as well as democratisation that led to open access and the opening-up of the social conscience of universities.

From this brief overview it is evident that a university concerns itself with knowledge, the training of professionals and educating people.

Policy documents build on a similar understanding of a university and deal in more detail with the nature, development and application of knowledge. Despite several policy documents on the restructuring of South African higher education and its landscape, there is no clear definition in the policy documents of what a university is. The concept of a university is rather understood against the background of what universities should be. From a science perspective this can be regarded as a limitation. To identify tasks for a university and then to conceptualise a university on the basis of these tasks is logically inconsistent. What happens in this approach is that the desired role for universities is projected onto the nature of a university. The correct approach would be first to obtain clarity on exactly what a university is (the nature thereof) and then to indicate what its functions should be. One cannot use the characteristics of an entity to identify the nature of the entity instead of analysing the entity to identify 


\section{PART TWO • NORMATIVE AND EPISTEMOLOGICAL ISSUES}

the ensuing characteristics of the entity (see Lategan 2005)! This is evident from the National Plan for Higher Education (2001) and its forerunner the National Commission on Higher Education (NCHE) (1996a; 1996b), as well as from planning documents such as the National Education Policy Investigation (NEPI) (1993) and the Size and Shape Report (CHE 2000). The Higher Education Act (Act 101 of 1997 and all its amended forms) (South Africa 1997) does not give direction either. This does not mean that policy is not valuable in understanding what a university is. It simply means that yet another perspective is needed to unpack the university. In this regard I suggest that conceptual knowledge be used to comprehend the university. This means that rational analysis of reality can assist one in understanding the individual and universal character of an institution. By 'individual' is meant that only the form of the society concerned can determine the specific task. 'Universal' refers to different forms of society influencing one another. The individual and universal side of things can be explained in the following way: the church and the university both have a teaching function. The church undertakes religious instruction, while the university is accountable for academic instruction. Although the preparation of a sermon presupposes a particular exegesis, methodology and academic grounding, the sermon never degenerates into an academic lecture (at least, it should not!). Occasionally a lecturer may pass a religious judgement, but this does not change his/her lecture into a sermon. Even the presence of a faculty of theology does not turn a university into a church - just as a faculty of law does not turn it into a civil court. Therefore, although different forms of society influence one another, the one cannot take over the functions of the other. Built on this conceptualisation, it may be concluded that a university is qualified through knowledge which is further specified as scientifically oriented research and teaching. In the light of this, the following definition of a university may be rendered:

A university is an academic institution at which research is conducted and teaching/learning is offered within the organised cadre of the contact between lecturer and student.

Dillemans (2006) rightly emphasises the fact that a university exists because of science. It would therefore be safe to argue that this core function should be found in a university regardless of the university type. This view is supported by the Higher Education Act (No 101 of 1997, amended) which states that higher education institutions should be engaged in teaching/learning, research and service. The Size and Shape Report (CHE 2000) and the National Plan for Higher Education (2001) support mission and activity differentiation, though not different missions and activities. Within the context of the South African higher education band, three university types can be identified: classical 
universities, comprehensive universities and universities of technology. These university types share the core university activities as common denominator.

Where does this leave the core activities of a university (and its adjectives)? One may answer that the university functions are the same (still teaching/learning, research - therefore the functions are constant), but that these functions have taken a new direction (for example, contract research, commercialisation, innovation, applied research - therefore the dynamics of the functions). Two important conclusions can be drawn based on these arguments:

- If an institution is not engaged in teaching and research, then it cannot qualify as a university.

- Regardless of how a university changes, the core activities of the university should always be found back in its activities.

A question not yet addressed is that of service. Is this a core activity next to teaching and research or is it an activity following on teaching and research? On the one hand there is the point of view of the so-called Traditionalists. This group advocates the standpoint that the traditional identity of the university should be maintained. On the other hand, the so-called Pragmatists/Progressivists advocate contemporary relevance. Within both groups of opinion-makers, there is considerable consensus that the task reserved for the modern university is teaching and research. The way in which it should be concretised, however, elicits widely varying opinions. The Pragmatists regard active community service as a third task of the university, while the Traditionalists already regard the typical task of the university as community service. I have always favoured two arguments in support of the latter view. The first argument is that the best (community) service a university can render is to be active in its core activities. There is no point in the university being all things to all people, but not being able to be a good university. Society needs universities that can enlighten it (society), and not universities that undertake all kinds of activities except those in which the university should be engaged. This does not mean that the university cannot direct its activities to change or support society. A good example is a remark in the UNESCO's Report on Higher Education in the Twenty-first Century (1998) on the role of the African university. This report states that due to a lack of democracy in Africa and a lack of sufficient support systems for society, universities can assist government, business and industry in addressing these challenges. The universities therefore have a developmental role to take on. It goes on to say that no university can afford not be engaged in society. The ivory tower image of the university symbolises an institution removed from the realities 


\section{PART TWO • NORMATIVE AND EPISTEMOLOGICAL ISSUES}

of society. The university remains a societal structure and must contribute to society at large.

A perspective that may help one to understand the service of the university is the concept of engagement. Engagement simply refers to how the university engages with business and industry in addressing societal challenges. Engagement with society offers the university the unique opportunity to develop and transmit from and to society. An appropriate example may be found from the military. Castells (2001 b:209) makes the important remark that American universities got a major boost from World War II and the Cold War when it was required of universities to serve the needs of the military. Thomas (2000:53) has the same perspective. He refers to engineering practice prior to World War II. During that period, engineering was largely rule- and experience-based. This changed after World War II due to the defeat of Germany and Japan and especially in the pursuit of the Cold War. He further remarks that this engagement elevated the promotion of science and technology to unprecedented levels. This practice confirms a common strategy to reflect the engagement activities in the curriculum. It serves no purpose to engage with society if there is no spin-in to the core business of a university. It is in this context that the question of 'fitness for purpose' can be cited. If engagement has no positive impact on the university itself then one may wonder whether engagement was for the right reasons. Engagement is never about doing something for a community, but always about doing something with the community.

The engaged university is faced by another challenge: stakeholders. Neave (2001) correctly refers to employers, investors and customers as stakeholders. Students are regarded as one of the stakeholders, especially as customers. Neave (2001:22) regards them as more than agents of demand. He remarks that "governments came increasingly to see the student body as prime channel for the direct transmission into higher education of society's press for change". The stakeholder is a "conceptual being" and influences the university as institution. He refers to attempts to construct typologies of stakeholders. From these typologies it is quite clear that the university as organisation cannot be removed from its internal and external stakeholder. Umesiobi's (2006) study confirms that internal stakeholders are as important to the university as external stakeholders.

What should also be noted is that the university should exercise its choice regarding which market it wants to serve. The market ranges from local, regional and national to international (Neave 2001). It remains a pity that many (South African) universities 
want to be universities for all instead of serving only the community or communities they have the capacity to serve. Another tragedy is that universities are often good at setting up (inter)national partnerships, but poor at collaborating with local and regional partners. One possible reason for this is the common belief that an international partner can bring more prestige to a university than a local partner. A positive result of this approach may be that the international partner connects the university with the global village and assists with its (the local university's) participation in international education.

These few comments on a university, its nature and it functions, point out that the university is a unique societal structure that is integrated with society. It is quite obvious that through the ages the university always had a close relationship with society. This relationship is not only defined on the basis of society's scientific needs, but also by how universities employ society to carry out their mission.

\section{STATIONS ALONG THE WAY: VARIOUS IMAGES OF A UNIVERSITY}

Universities (in South Africa) undergo periodic redefinition. Here, the Heraclitic concept of panta rei - everything changes (moves) - is true. Different values in the university have resulted in different views on these institutions, which in turn have led to different expectations of universities. It is noticeable that three university ideals dominate university life. The ivory tower idea embodies the ideals of the Humboldian university (academic freedom at all costs), the new social role engages the Newman ideal (personal development) and the Napoleonic ideal (state regulation) has government as major partner and stakeholder of the university. In my research I found fragmentations of these 'images' back in universities. Consider the following images:

\section{Image 1: Racial and political universities}

Due to the previous composition of South African society as well as previous policies on universities, universities were classified in three distinct groupings, viz. Englishmedium universities, Afrikaans-medium universities and black universities. Needless to say, each of these types serves only the interests of its particular clientele. (Note that the first two groupings of universities were classified by language, while the latter grouping was classified by race.) This division provided the ideal climate for the politicisation of universities. Student bodies contributed to the enhancement of the politicisation of academia. The Afrikaanse Studente Bond was a gateway for Afrikaans students to take up prominent posts in society. English students were more interested in freedom of speech than in challenging the Calvinistic values ('Christian National Education') 


\section{PART TWO • NORMATIVE AND EPISTEMOLOGICAL ISSUES}

of the universities, while black universities propagated the slogan "Liberation before education". The impression is that the situation has not changed at all. One ideology has been replaced by another. In the past the emphasis was on Christian National Education (as ideology); now it has made room for Work Integrated Learning (also an ideology); equity and redress are uplifted as neo-liberal values in the place of merit only (neo-conservative value). Language is a dividing factor instead of an empowering factor to communicate cross-culturally and cross-nationally. The staggering of these examples simply says that the university has difficulty in escaping its political affiliation.

\section{Image 2: The 'free university'}

In the simplest terms university autonomy refers to the degree of self-governance of a university. Thus university autonomy entails the internal power of the university. In accordance with the private act on the university, it does have the competence to determine its own style and direction. The university arranges, in accordance with its own private act, matters such as the content and method of instruction, examination and the awarding of degrees. With this the university remains within the bounds of its competence as academic life form and at the same time it provides room for the university to implement internal self-management. This important value is challenged by a state-directed intervention characterised by transformation agendas, redress and social redress. Although important, a serious problem is that the transformation of the core university functions is not as high on the agenda as it should be. This is one of the biggest challenges facing universities in the world in considering whether their activities are still fit for their purpose.

Universities' freedom has also been challenged by funding policies. The current South African practice to fund research outputs (postgraduate degrees and publications) is acknowledged to build capacity and reward performance at the research level. What has not yet been sufficiently debated is the way in which funding influences what universities are doing. There is still the untested perception that academics are now writing articles to earn credits and not to expand the knowledge base of their discipline. If this is true, then creativity has been straitjacketed by funding.

The freedom of the university is not only challenged by state intervention, but also by the steering of its intellectual capabilities. The 'enterprise' has become the leading chorus of scientific activities and dictates to the university what should be on the agenda (see Lategan and Hooper 2009). Although this relationship has many positive benefits for 
the university, it remains a dominant power on the university agenda which leaves very little space for academic freedom.

\section{Image 3: The market-driven university}

The global economy, as well as information and communications technology, has compelled educational institutions to adopt a market-driven approach. This does not mean that a higher education institution should become a business - rather, it implies that business-like decisions and approaches should drive the core business of the university. An example of the latter is curriculum reforms reflecting educational, pedagogical, business and social values. Ensuing from this would be new learning approaches such as knowledge development. Knowledge development recognises the fact that learning outside the classroom and laboratory is becoming more important than learning within the classroom (so-called borderless learning). Institutions offering virtual and life-long education will secure employability instead of a job. What universities find in the era of customer service is that teaching itself is not enough. It is the kind of teaching offered that matters. Universities realise that prospective students are striving to study at the best institution (depending on different criteria). Universities have started to value students as clients, and students demand to be treated accordingly. Hawkins (1995) states that preparing graduates for employability goes far beyond the individual input of the student, the approach of higher education or the concerns of governments. He also states that career tactics are the concern of all people wishing to enter the world of work. A fundamental principle underlying career tactics is the learning of skills. Graduates (as important higher education customers) cannot prepare for their careers on their own. Career management must be viewed as a shared responsibility between the organisation and the individual.

No one of these images is the ideal image of a university, although each contributes towards the understanding of what a university is. In addition, one should not be too worried that there are so many (conflicting) images and expectations of what a university is. Kerr (1995:7) correctly observes that "[t]he university is so many things to so many different people that it must, of necessity, be partially at war with itself". Popma (1997) too, encourages one to keep on researching the "university in movement". There is not a fixed perspective as to how a university should be dealing with its core activities. Van Vught (1997) correctly says that it is easier to ask what a university is than to answer this question. 


\section{A MOMENT OF ENLIGHTENMENT}

In researching the university, valuable lessons have been learned with regard to higher education research. Four observations are made which do not only give direction to research on the university, but also to higher education in general:

- The researcher either clings to one paradigm which almost leads to a standard set of conclusions or the researcher does not subscribe to a set of scientific values, with the result that the conclusions very often lack merit and foundation. On a personal level, I am happy to report that even in the course of this chapter, I have shifted some of my own perspectives - a moment of enlightenment to understand things in a different way. However, I have also experienced that some perspectives and examples are contested through time and can be validated. I have to admit that scientific perspectives are both constant and dynamic - a missing link in many scientific debates. I therefore call upon intellectual fairness when arguments are formulated, revisited and validated.

- The danger exists that research results can very often be recycled (cut and paste approach) with no new results produced to further one's understanding of the topic. In my own research I have often discovered that one may have a fixed view on a topic and that more evidence is accumulated to support the view instead of asking whether the particular view still holds water. Here too, intellectual fairness must be applied.

- An emerging challenge for research is the quest for research integrity. The staggering of known evidence serves no purpose in research development. I am very much aware that one can (theoretically) not plagiarise one's own research, but the danger remains that existing knowledge may be recycled/repackaged and presented as something new when it is not new at all. This opens the debate for research integrity.

- Another form of enlightenment is the sharpening of one's conceptual knowledge. I am once more convinced that the mastering of this skill is imperative for higher education research. Without really understanding the meaning of a concept it is difficult to do research or to draft appropriate conclusions.

\section{LESSONS LEARNED DURING THE JOURNEY}

Several lessons have been learned during my journey to understand what the university is. The following lessons should give direction to stimulate the debate: 
As already stated, the university as organisation is central to all higher education studies. It is imperative to keep asking the question: "What is a university?" A range of people, starting from policy makers, university managers, lecturers, researchers and students, to businesspeople and industrialists, should know what a university is. To this extent it is an elitist institution in the sense that it is continuously subjected to analysis, review and discussion. The irony is that although conceptual answers are possible to this question there will always be an illusive side to the comprehension of exactly what a university is. After all, is this not what is expected from the 'intellectual home' of society?

As research object the university needs to be subjected to a problem statement, research methodology, analysis and conclusions. It is noticeable that scholars of the university either have no valid research methodology or their conclusions are based on personal opinions and orientations only. It is also observable that scholars at the university study more managerial or institutional issues and conclude, on this basis, what a university is. As already argued in this chapter, studies in management and institutional issues inform institutional behaviour and performance, but not conceptual understanding. It would be wrong to confuse the two approaches with each other and it would be equally wrong to think that it is of lesser importance to know how a university works and performs.

It would be impossible to understand the university without a philosophical framework. Take, for example, the Size and Shape Report (CHE 2000), which lacks an embedded theoretical paradigm. A post-modern view (any view holds ground) is characteristic of this report (and many other reports). It should still be proven that the Department of Education is not in the grip of relativism (remember the NCHE - not institutions, but programmes), pragmatism (gender, race, equity, etc.) and the over-generalised view that higher education will lead to the improvement of the economy (which economy?) and employability (career-specific or simply skills-based?).

Universities have to accept that they have lost their monopoly on knowledge development. The most innovative research and best laboratories are often found outside universities (for example, Silicon Valley). This new development forces universities to partner with business and industry. The good news is that these partnerships can only benefit the university. Positive examples are the availability of funds and facilities, quick turn-over time (opposed to the bureaucratic practices at universities), the applicability of the research and its results and that universities are reminded that they have to continuously renew the way in which their core business is practised. Two negative results of these 


\section{PART TWO • NORMATIVE AND EPISTEMOLOGICAL ISSUES}

partnerships are that the partners very often tell universities what to do (universities should know the innovation, not the other way around) and universities can easily become followers instead of leaders in a field.

In the knowledge economy knowledge is seen as 'raw' material. The result is that universities can sell their product (read knowledge). In doing so, the universities are acting like enterprises competing on the open market. The positive result is that universities should revisit their way of doing things to fit into a competitive environment. The negative results are that universities can easily abandon their academic responsibilities and cling only to enterprise behaviour, or that the universities may not be skilful enough to engage with a changing environment. The challenge for universities is to deliver programmes that can contribute towards knowledge-based professions.

Universities cannot only train people; they also need to educate them. Very often a clash is observed between the demands of the workplace (experts, professionals and skilled people) and what the origin of a university entails (intellectual concept crafters). It would be wrong to say that universities have no training responsibility. Even medieval universities acted as vocational schools. It is also an invalid assumption to think that work-directed education is a college activity and work-relevant education a university approach. Universities have to take the lead in training experts, professionals and skilled workers for the market. The training of students, though, should never exclude scholarship. Apart from having work-related abilities, students need to be scholars. If they are not, how will they ever be able to identify new problems and formulate new solutions if their training is limited to manual issues only? South African society runs the risk of having trained graduates, but not scholarly graduates. In a market-driven approach disciplines like philosophy are often in jeopardy since they are less of an income generator than, for example, MBA graduates.

A stimulated academic heartland, a concept used by Burton Clark (1998) and Frans van Vught (1997), amongst others, is central to the university. Conceptual knowledge needs to unpack the exact meaning of the university's present-day core activities. Academics should practise their field of study and research in such a way that the core activities are strengthened. This assignment is built on academics' scholarly and professional commitment. The Academy of Science in South Africa's report on scientific writing in South Africa alludes to the fact that in spite of growth in research publications, not all of these publications are of a scholarly nature. Several reasons can be listed why academics are not stimulating the academic heartland in South Africa. To list a few: students are under-prepared for higher education; too much lecturing time is 
spent on remedial activities rather than on creative ideas; universities cannot attract the best scholars, because international universities offer better opportunities and marketrelated jobs, which are more financially attractive; students are more interested in obtaining a qualification for market purposes than becoming scholars in their field; and transformation is limited to political issues, whereas knowledge transformation should question the way in which universities are dealing with knowledge in a changing world.

It is often forgotten that although the university is a structure consisting of core activities, a structure is not something abstract or a conceptual construct only. Universities consist of people - staff, students, partners, etc. The most important assignment for a university is to invest in human potential and to create human capital that can be invested in society. Too often the university is limited to mortar and bricks. This is the physical appearance of a university. A university is a collection of people who relate to knowledge - some as transmitters of knowledge (teaching), some as generators of knowledge (research), some as managers of knowledge (rectorate), some as seekers of knowledge (students), some as users of knowledge (business and industry) and some as end users of knowledge (society). But it is people who collectively constitute a university. This observation is too often omitted when we research the university.

\section{POSTSCRIPT: SENDING OUT POSTCARDS}

It would be presumptuous to think that almost a millennium of university history can be reflected on in a single chapter. It would be equally arrogant to state that the university is now fully understood. It is more modest to say that the university is conceptually a definable organisation. It is challenging for the university to state that it wants to engage with societal challenges, but it is difficult to identify appropriate strategies to address these challenges via its core functions. The university always stands before a window of opportunity. But, as soon as one opens this window, the university has moved on to another. In this sense the university is an elusive concept always willing to be subjected to research.

A universal benchmark that has stood the test of time is how best the university can generate and develop knowledge in a society. This remains the true social role of a university. To define a university simply in the context of its social role does not do justice to the fact that a university is an academic institution. 


\section{REFERENCES}

Bok D. 2003. Universities in the marketplace: The commercialization of higher education. Princeton: Princeton University Press.

Castells M. 2001 a. The new global economy. In: J Muller, N Cloete \& S Badat. Challenges of globalisation. Pretoria: Maskew Miller Longman. 2-21.

Castells M. 2001 b. Universities as dynamic systems of contradictory functions. In: J Muller, N Cloete \& S Badat. Challenges of globalisation. Pretoria: Maskew Miller Longman. 206-223.

Clark B. 1998. Creating entrepreneurial universities. Paris: IAU and Pergamon Press.

CHE (Council on Higher Education). Size and Shape of Higher Education Task Team. 2000. Towards a new higher education landscape. Meeting the equity, quality and social development imperative of South Africa in the $27^{\text {st }}$ century. Pretoria: Department of Education.

Dillemans R. 2006. Kennis als verantwoordeliikheid en ethische opgave. In: B Pattyn \& Van G Overwalle (eds). Tussen markt en Agora: Over het statuut van universitaire kennis. Leuven: Peeters. 7-29.

Hawkins P. 1995. Skills for Graduates in the 21 ${ }^{\text {st }}$ Century. Cambridge: The Association of Graduate Recruiters.

Kerr C. 1995. The uses of a university. Cambridge: Harvard University Press.

Lategan LOK. 1989. Die wese van die Universiteit. Published MA dissertation awarded by the University of the Free State. Bloemfontein: VCHO.

Lategan LOK. 1996. Images of the university: Which image would best serve the interest of the university in South Africa? Tydskrif vir Christelike Wetenskap, 32(1\&2):56-72.

Lategan LOK. 1998. The nature of a technological university within the context of the South African higher education band. Inaugural lecture. Bloemfontein: Technikon Free State. 26 November.

Lategan LOK. 2000. Revisiting the idea of a university. In: LOK Lategan (ed). The making of a university of technology. Bloemfontein: Technikon Free State Studies in Higher Education No. 3:1-14.

Lategan LOK. 2005. Relativism in national higher education policy documents: What is a university? Acta Academica, sup (2):185-201.

Lategan LOK \& Hooper P. 2009. Ethics, governance, research and enterprise. Perspectives, 13(2):55-60.

National Commission on Higher Education (NCHE). 1996a. A framework for transformation. (First draft.) Pretoria: Department of Education.

National Commission on Higher Education (NCHE). 1996b. A framework for transformation. (Final recommendations.) Pretoria: Department of Education.

National Education Policy Investigation (NEPI). 1993. The Framework Report. Cape Town: Oxford University Press.

National Plan for Higher Education (NPHE). 2001. National Plan for Higher Education. Pretoria: Ministry of Education. 
Neave, G. 2001. On stakeholders, Cheshire cats and seers: Changing visions of the university. Inaugural address as professor of Comparative Higher Education Policy Studies at the University of Twente. Enschede: University of Twente. March.

Plato. 1964. Kratylos. In The dialogues. New York: Bollingen Foundation.

Popma Th JA. 1997. Wat beweegt ons? Address as outgoing Rector Magnificus at the University of Twente. Enschede: University of Twente.

South Africa (Republic). 1997. Higher Education Act. Pretoria: Government Printers.

South Africa (Republic) Minister of Education. 2001. National Plan for Higher Education. Pretoria: Department of Education.

Teichler U. 2007. Higher education systems: Conceptual frameworks, comparative perspectives, empirical findings. Rotterdam: Sense Publishers.

Thomas G. 2000. The creation of a technological university: An example from the USA. In: LOK Lategan (ed). The making of a university of technology. Bloemfontein. Technikon Free State Studies in Higher Education No. 3. 52-63.

Umesiobi D. 2006. The role of research partners in supporting research outputs in higher education institutions: Insights from the Central University Technology, Free State. Unpublished MA dissertation. University of the Free State.

UNESCO. 1998. Higher Education in the Twenty-first Century. Final report. Paris: UNESCO.

Van Vught FA. 1997. De nieuwe academische collegialiteit. Inaugural address as Rector Magnificus at the University of Twente. Enschede: University of Twente. 